\title{
Arborescent 'Treetop' English Ivy
}

\author{
R.E. Davis ${ }^{1}$, T.E. Bilderback ${ }^{2}$, and P.R. Fantz ${ }^{3}$ \\ Department of Horticultural Science, North Carolina State University, \\ Raleigh, NC 27695- 7609
}

Additional index words. Hedera, ornamentals breeding, Araliaceae

English ivy [Hedera helix L. (Araliaceae)] has been cultivated for centuries as an attractive ornamental ground cover and vine. Foliage is a lustrous dark green with whitish veins. Plants have two morphological phases: Plants in the nonflowering juvenile phase typically bear lobed leaves and adventitious roots by which they climb. The adult phase commonly occurs well off the ground with branches becoming much more woody, bearing ovate, unlobed leaves, and lacking the adventitious roots. These branches are reproductive, bearing the flowers and fruits. A few adult clones exist in the European ornamental industry (Rose, 1988) but are not available in America. There are numerous clones of juvenile phases available, yet adult clones are eagerly desired as a landscape plant according to Sabina Mueller Sulgrove, registrar, American Ivy Society (personal communication, 1990). Hedera helix 'Treetop' is an adult arborescent clone of English ivy that bears flowers and fruits and can be propagated for cultivation (Fig. 1).

\section{Origin}

Twelve cuttings were obtained from a robust unidentified cultivar of English ivy that was climbing a large Pinus taeda L. near the campus of North Carolina State Univ., Raleigh. These were propagated successfully and became stock plants for further propagules developed by R.E. Davis at Johnson Nursery Corp., Williard, N.C. The source was destroyed when the pine tree and ivy were cut down.

\section{Description}

'Treetop' is an erect shrub. Young branches are bright green, 3 to $6 \mathrm{~mm}$ in diameter, with white, star-shaped trichomes. Leaves are alternate, petiolate, ovate to deltoid-ovate, 3.5

Received for publication 31 July 1991. Accepted for publication 9 Oct. 1991. The use of nursery and trade names in this publication does not imply endorsement by the North Carolina Agricultural Research Service of the nursery or the products mentioned, nor criticism of similar ones mentioned. The cost of publishing this paper was defrayed in part by the payment of page charges. Under postal regulations, this paper therefore must be hereby marked advertisement solely to indicate this fact.

${ }^{1}$ Johnson Nursery Corp., Box 12\%1/2, Willard, NC 28478. Current address: The Ivy Farm, 1523 Longwood Dr., Norfolk, VA 23508.

Associate Professor.

${ }^{3}$ Professor. to $8.5 \mathrm{~cm}$ long, 2.5 to $8 \mathrm{~cm}$ wide, with a rapidly tapering acute apex and a rotund to truncate base. Leaf margins are entire, somewhat undulate, occasionally bearing a small basal lobe (thus appearing three-lobed). Leaf venation is basally five-palmate, with the lateral pair occasionally ending in a small tooth. Petioles are up to $9 \mathrm{~cm}$ long, scattered stellate, with a concave clasping sheath 4 to $5 \mathrm{~mm}$ long, 5 to $6 \mathrm{~mm}$ wide, and up to 1.5 $\mathrm{mm}$ high. Inflorescences are axillary and bear terminal umbels with 20 to 25 flowers. Pedicels are 13 to $17 \mathrm{~mm}$ long and stellate pubescent. Involucral bracts are concave-ovate, acute, and $\approx 2 \mathrm{~mm}$ long $\times 1 \mathrm{~mm}$ wide. The perianth is five-merous and actinomorphic. The calyx tube is $\approx 2 \mathrm{~mm}$ long with minute, deltoid lobes that are $1 \mathrm{~mm}$ long and broad. The five petal lobes are borne from the disk upon the ovary's apex. They are 4.5 to 5 $\mathrm{mm}$ long, 2.5 to $3 \mathrm{~mm}$ wide, yellowish-green, keeled medially and marginally above, and spread nearly $90^{\circ}$ from ovary. The five stamens have filaments 2.5 to $2.7 \mathrm{~mm}$ long that spread radially from the ovary. The versatile extrose anthers are $\approx 1 \mathrm{~mm}$ long. The ovary is subinferior, glandular, weakly ribbed, $\approx 4$ $\mathrm{mm}$ in diameter $\times 1.5 \mathrm{~mm}$ long, and ovoid with a rapid tapering to the style. The $1-\mathrm{mm}$ style is thick-columnar and tapers gradually to a truncate apex (Fig. 2). Plants produced $\approx 30$ to $38 \mathrm{~cm}$ of shoot growth each growing season in North Carolina. Young plants may exhibit reversion to the juvenile phase in horizontally spreading shoots near the base of the plant. Minimal pruning of these shoots until plants age and obtain more biomass will eliminate this problem. Older plants have not exhibited this reversion.

New leaves are bright green concolorous with both surfaces (vidi $30 \times$ ) bearing scattered stellate trichomes and minute scales. Older leaves become dark green above with a pale to whitish hue around the major veins. The lower surface continues to bear minute scales, whereas the upper surface becomes glabrous.

\section{Culture}

Softwood cuttings are prepared from selected vegatative shoots of 'Treetops'. Each cutting is 8 to $10 \mathrm{~cm}$ long with two to three nodes. A light wound to a depth that reaches the secondary xylem is administered to the basal $12.8 \mathrm{~mm}$ before being dipped in Rootone talc $[0.1 \%$ indole- 3 butryic acid, $0.20 \%$ 1-naphthaleneacetamide, and $4.04 \%$ tetramethyl thiuramdisulfide, (thiram)] with excess powder removed. Each cutting then is

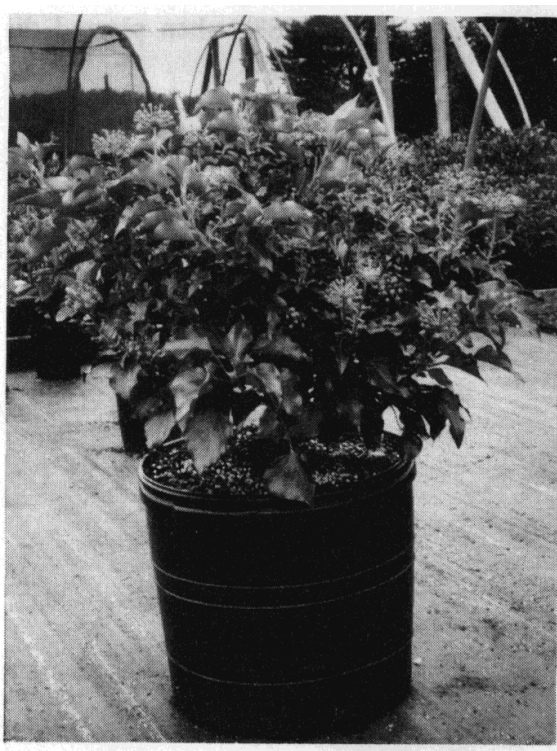

Fig. 1. Hedera helix 'Treetop' (American Ivy Society registration no. 910292; AIS 91-055), an arborescent clone of English ivy.

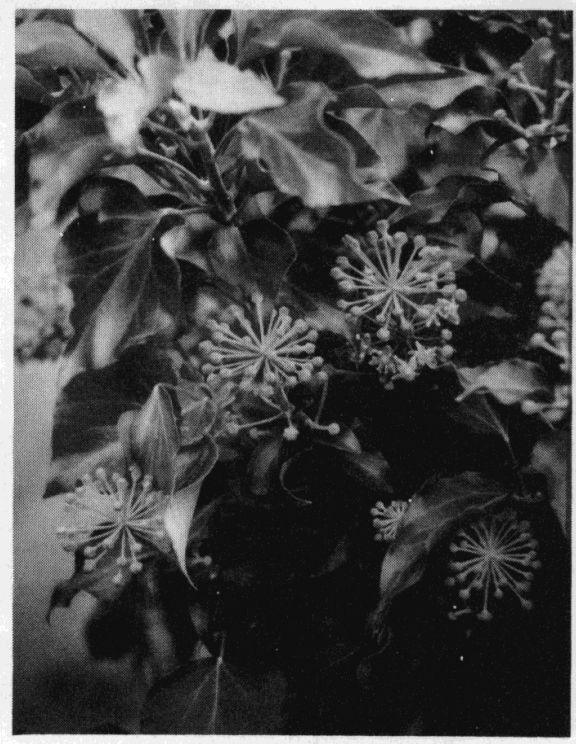

Fig. 2. Leaves and inflorescences of 'Treetop' English ivy.

inserted into propagation medium composed of 2 coarse perlite : 1 peatmoss $(\mathrm{v} / \mathrm{v})$. Trays with cuttings are placed in a propagation greenhouse covered by a $40 \%$ black shadecloth. Intermittent mist operates $5 \mathrm{sec}$ every 15 min from 8:00 AM until 4:00 PM.

Cuttings root in $\approx 8$ weeks and are potted into 3.8-liter containers with a 16 pine bark : 1 sand medium (v/v) and grown in full sun with overhead impact sprinkler irrigation. Plants grown under moist, shaded conditions have been observed to occasionally develop leaf spot.

'Treetop' has potential as a container plant to be used in interior landscape displays and around decks, patios, and pools. 'Treetop' may be used as a specimen plant or a low 
ivy hedge (Rose, 1988) when planted directly into the landscape.

Availability

'Treetop' is being registered with The
American Ivy Society, Dayton, Ohio (American Ivy Society registration no. 910292; AIS 91-055). Information on 'Treetop' availability in sizes ranging from 11 to 55-liter con- tainers can be obtained from R.E.D.

Literature Cited

Rose, P. 1988. In praise of ivy. The Garden 113(9):418-426. 